\title{
Entomopathogenic nematodes for the control of Helicoverpa armigera (Hübner) (Lepidoptera: Noctuidae) pupae
}

\author{
Vanessa Andaló1,* (D) https://orcid.org/0000-0002-6310-1680 \\ Lucas Silva de Faria' (D) https://orcid.org/0000-0003-1948-6533 \\ Fabio Janoni Carvalho² (D) https://orcid.org/0000-0002-0327-1821 \\ Gleice Aparecida de Assis ${ }^{1}$ (D) https://orcid.org/0000-0003-0239-1474 \\ Viviane Santos ${ }^{3}$ (D) https://orcid.org/0000-0001-5196-0878 \\ Simone Martins Mendes ${ }^{4}$ (D) https://orcid.org/0000-0002-9773-9017 \\ Alfredo Henrique Rocha Gonring ${ }^{5}$ (D) https://orcid.org/0000-0003-4120-4360 \\ 1. Universidade Federal de Uberlândia - Instituto de Ciências Agrárias - Monte Carmelo (MG), Brazil. \\ 2. Instituto Federal do Triângulo Mineiro - Uberaba (MG), Brazil. \\ 3. Instituto Federal de Mato Grosso do Sul - Dourados (MS), Brazil. \\ 4. Embrapa Milho e Sorgo - Sete Lagoas (MG), Brazil. \\ 5. Corteva Agriscience - Du Pont do Brasil S.A. - Paulínia (SP), Brazil. \\ *Corresponding author: vanessaandalo@ufu.br
}

\begin{abstract}
Helicoverpa armigera (Hübner) is a polyphagous insect of difficult control and maize is an important host crop of this insect. Entomopathogenic nematodes (EPNs) are control agents of soil pests. This study aimed to verify the action of EPNs for the control of $\mathrm{H}$. armigera pupae. Laboratory and greenhouse bioassays were conducted to select the concentration of nematode application and subsequently field test were conducted. It was obtained that Heterorhabditis amazonensis MCO 1 at the concentration of 400 infective juveniles (IJs) $\cdot$ pupa $^{-1}$ caused the highest mortality in a lower concentration, whereas for $H$. amazonensis JPM4, concentrations of both 200 and 400 IJs $\cdot$ pupa $^{-1}$ were similar causing pupae mortality. In the greenhouse, $H$. amazonensis MCO 1 caused mortality reached values of $80 \%$ after 10 days, at concentrations of 600 and $800 \mathrm{IJs} \cdot$ pupa $^{-1}$. The highest mortality caused by Steinernema carpocapsae was observed at eight days after the juvenile application, at a concentration of $600 \mathrm{IJs} \cdot \mathrm{pupa}^{-1}$, also reaching $80 \%$ mortality. In the field test, both forms of application were considered appropriate for $\mathrm{H}$. amazonensis MCO 1, causing mortality rates of up to $80 \%$.
\end{abstract}

Keywords: biological control; Heterorhabditidae; Steinernematidae; Zea mays.

\section{INTRODUCTION}

Helicoverpa armigera (Hübner) (Lepidoptera: Noctuidae) is a cosmopolitan pest that feeds on at least 170 species of plants, including important crops, since cotton, soybean and beans (JHA et al., 2012). Maize (Zea mays L.) is one of the main hosts of this insect. The caterpillars prefer to feed on the shoots and reproductive organs of plants, resulting in high annual costs spent on control, besides production losses that reach US\$ 5 billion (LAMMERS; MACLEOD, 2007; CZEPAK et al., 2013). Other characteristics of this species are its high mobility, fecundity and ability to survive. These characteristics favored the establishment of this insect in Brazil, where it has easily reached the status of pest and has become a major phytosanitary problem in several maize-producing regions of the country (ÁVILA et al., 2013).

According to the Brazilian Ministry of Agriculture, Livestock and Supply, there are 44 chemical and biological insecticides registered for the control of $H$. armigera in soybean, including emamectin benzoate, that was not registered

Received: Oct 18, 2019 . Accepted: Oct 30, 2020

Associate Editor: Silvia Galleti

Peer Review History: Double-blind Peer Review. 
in the country until 2017 (MAPA, 2020). However, in different parts of the world, cases were found of H. armigera resistance to the main insecticides used for its control. Thus, it is fundamental to associate different control methods to reduce selection pressure on the pest (KAMARAJ et al., 2008).

About $30 \%$ of the insecticides used worldwide are directed to this species, mainly due to the high levels of resistance (UDAMALE et al., 2013). Helicoverpa armigera has a great ability to develop resistance to insecticides, and also an ability to develop resistance to Cry proteins introduced in genetically modified plants, which are toxic to larvae (AKHURST et al., 2003). In this way, different strategies should be considerate to control H. armigera.

Biological control using entomopathogenic nematodes (EPNs) can be effective to assist in the control of H. armigera. Different studies report the use of EPNs for the control of prepupae and pupae of Spodoptera frugiperda (Smith) (Lepidoptera: Noctuidae) and Helicoverpa zea (Boddie) (Lepidoptera: Noctuidae) in maize, reaching high mortality rates (FEASTER; STEINKRAUS, 1996; ANDALÓ et al., 2010). As these insects present a habit of life similar to H. armigera, it is important to study EPN as a biological control agent of this pest.

Nematode species, such as Heterorhabditis amazonensis Andaló, Nguyen and Moino Jr. (ANDALÓ et al., 2006) and Steinernema brazilense Nguyen, Ginarte, Leite, Santos and Harakava, have been described in Brazil (NGUYEN et al., 2010). The use of native species is closely related to the success of control programs due to the adaptation of the nematode to the environment and the specificity to the target insect. Entomopathogenic nematode can be also effective to target insects living in the soil or in cryptic environments (ARTHURS et al., 2004), which is the same condition where H. armigera pupae remain.

Considering the potential of EPNs in the control of $H$. armigera pupae and the possibility of using native populations adapted to local conditions, this study aimed to verify the action of EPNs for the control of H. armigera pupae in laboratory, greenhouse and field conditions.

\section{MATERIAL AND METHODS}

The establishment of $H$. armigera in laboratory was performed according to the methodology described by VILELA et al. (2014).

To obtain recently emerged infective juveniles (IJs), the populations stored in aqueous suspension in a climate chamber at $16 \pm 2{ }^{\circ} \mathrm{C}$ were multiplied in larvae of Tenebrio molitor L. (Coleoptera: Tenebrionidae) raised according to the POTRICH et al. (2007) methodology. The larvae that died with symptoms of infection were washed with water and placed in a dry chamber (Petri dish with filter paper) for 5 days. After that, the larvae were removed and placed in white traps to collect the IJs. The infective larvae were kept in a climate chamber at $26 \pm 2{ }^{\circ} \mathrm{C}$. Infective juveniles collected for up to 3 days after emergence were used in experiments.

\section{Entomopathogenic nematodes concentration: laboratory bioassay}

Helicoverpa armigera pupae that were up to 5 days old were used in the experiment. Concentrations of 100, 200, 400 and 600 IJs per pupa were tested. As control, only water was applied. The nematodes used were H. amazonensis MC01 (population isolated in Monte Carmelo, MG, Brazil) and H. amazonensis JPM4 (population isolated in Lavras, MG, Brazil).

The IJs suspensions were added to Petri dishes $(9 \mathrm{~cm}$ in diameter) containing Plantmax substrate (12.3 g) with five H. armigera pupae displaced partially buried. The applied suspension volume was the same for all treatments, $6 \mathrm{ml}$, in order to keep the substrate moist. Five replicates were performed per treatment in a completely randomized design. Evaluations of pupa mortality were performed after 5 days of IJs application. The dead pupae were kept in a dry chamber for 4 days for subsequent dissection and confirmation of mortality caused by the nematode. The experiment was conducted in a climate chamber at $26 \pm 2{ }^{\circ} \mathrm{C}$ and $12 \mathrm{~h}$ photophase. The data were submitted to analysis of variance and the means adjusted by the regression analysis $(\mathrm{p}<0.05)$, after the assumptions were met.

\section{Greenhouse bioassay}

The experiment in greenhouse tested the species selected from the concentration test and included the nematode Steinernema carpocapsae All (Weiser) (from Florida, USA) as a comparison, based on the nematode behavior, since 
S. carpocapsae presents a habit known as ambusher, while H. amazonensis is considered a cruiser (WILSON et al., 2012; ANDALÓ et al., 2017), and these characteristics can affect the success of pest control.

Five pupae of $H$. armigera aged up to two days were placed in a plastic pot $(1.4 \mathrm{~L} 10 \mathrm{~cm}$ in diameter) containing sterilized soil classified as dystrophic red latosol. The pupae were buried approximately $3 \mathrm{~cm}$ deep in the soil, and a suspension of

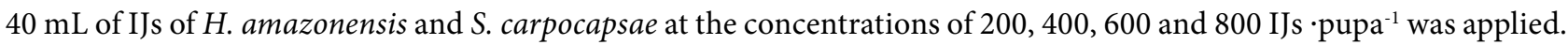
To the control was applied only water. Five replicates were performed per treatment, and the evaluations were performed $2,4,6,8$ and 10 days after the establishment of the experiment. To confirm mortality, the pupae were dissected and observed under a stereomicroscope to confirm the presence of nematodes. The data were submitted to analysis of variance and the means adjusted by the regression analysis $(\mathrm{p}<0.05)$, after the assumptions were met.

\section{Field bioassay}

The experiment was conducted in an experimental area in the domain of Plateau and Tablelands of the Paraná Sedimentary Basin ( $18^{\circ} 43^{\prime} 31^{\prime \prime}$ S, $47^{\circ} 31^{\prime} 32^{\prime \prime} \mathrm{W}, 890 \mathrm{~m}$ of altitude) in the southwest portion of the Brazilian Cerrado biome. The climate of the region is of Cwa type, according to Köppen classification. The soil of the area is classified as dystrophic red latosol, a moderate, medium texture, tropical Cerrado subdeciduous and mild wavy relief type.

Hybrid maize 'SHS 7920 Santa Helena' seeds were sown, spacing $50 \mathrm{~cm}$ between rows, plant density of 62,000 plants $\mathrm{ha}^{-1}$. The herbicides glyphosate, atrazine and 2,4 D, and chlorpyrifos insecticide for control of S. frugiperda were used at 40 days after plant emergence. The fertilization was carried out using $120 \mathrm{~kg} \cdot \mathrm{ha}^{-1} \mathrm{of} \mathrm{N}$ (30 $\mathrm{kg} \cdot \mathrm{ha}{ }^{-1}$ at planting and $90 \mathrm{~kg} \cdot \mathrm{ha}^{-1}$ coverage at $\mathrm{V} 4$ development stage), and at planting $80 \mathrm{~kg} \cdot \mathrm{ha}^{-1} \mathrm{P}_{2} \mathrm{O}_{5}$ and 60 $\mathrm{kg} \cdot \mathrm{ha}{ }^{-1} \mathrm{~K}_{2} \mathrm{O}$ were also used.

The experimental area was approximately $300 \mathrm{~m}^{2}$. The experiment was installed when the maize was at the R4 stage, about 30 days after pollination. The nematode tested was H. amazonensis MC01. Two treatments were used: the application of the aqueous suspension of nematodes and the release of nematodes via T. molitor cadavers. For the control, the nematode was not applied.

Tenebrio molitor cadavers containing the IJs were released every $\mathrm{m}^{2}$. For treatment with suspension, $80,000 \mathrm{IJs}$ in $1 \mathrm{~L}$ of suspension was applied per $\mathrm{m}^{2}$ with pressurized sprayer with $\mathrm{CO}_{2}$. Evaluations were done daily, for 5 days, starting 4 days after nematode release in the field.

The experimental design was a completely randomized block in subdivided plots; the first factor was the treatments and the second factor the evaluated days. Eight blocks were used, totaling 24 plots of $12 \mathrm{~m}^{2}$. Each plot received 10 pupae of $H$. armigera of up to 2 days-old that were buried at $3 \mathrm{~cm}$ depth and placed along the lines in the plot. Each place where the pupae were inoculated was marked for the subsequent evaluations.

The evaluated data were based only in $H$. armigera pupae mortality. None data of production were obtained, since it was not the objective of this study. Mortality data were submitted to analysis of variance, and the means were compared by the Tukey's test $(\mathrm{p}<0.05)$ and regression analysis, after the assumptions of the model were met.

\section{RESULTS AND DISCUSSION}

\section{Entomopathogenic nematodes concentration: laboratory bioassay}

Regarding concentration of IJs suspension to control H. armigera pupae, it was verified that mortality showed sigmoidal behavior, with a positive correlation between concentration mortality for H. amazonensis MC01. The dosage of $100 \mathrm{IJs} \cdot \mathrm{pupa}^{-1}$ was not efficient and did not differ from the control. Both concentrations of 400 and $600 \mathrm{IJs} \cdot \mathrm{pupa}^{-1}$ caused $45 \%$ mortality (Fig. 1 ). The lower concentration for spraying, $400 \mathrm{IJs} \cdot$ pupa $^{-1}$, was selected since it can offer a better ratio between economy and efficacy.

Considering $H$. amazonensis JPM4, the mortality followed exponential growth, and the concentration of $200 \mathrm{IJs} \cdot \mathrm{pupa}^{-1}$ was enough to cause $40 \%$ mortality in the insects. There was a reduction in the percentage of pupal mortality with increasing concentrations from 400 to $600 \mathrm{IJs} \cdot \mathrm{pupa}^{-1}$. This contrasted with what occurred with H. amazonensis $\mathrm{MC01}$, which presented an increase in pupal mortality rates associated with an increase in the concentration, and an establishment at the higher concentrations (Fig. 1). 
(a)

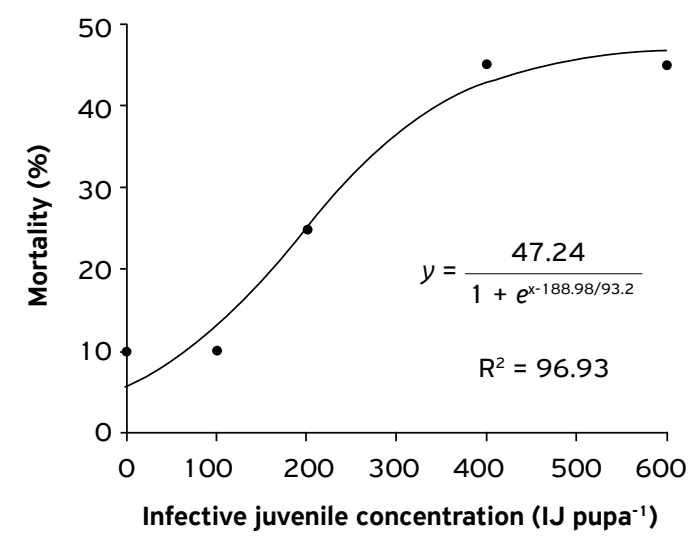

(b)

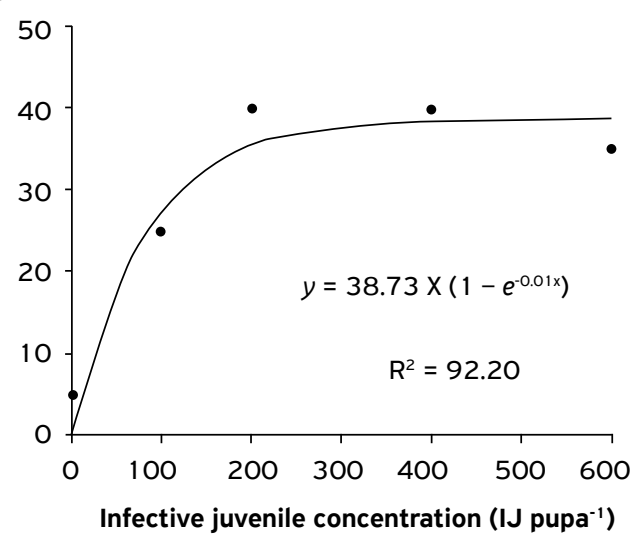

Figure 1. Mortality of $H$. armigera pupae caused by different concentrations of $H$. amazonensis MCO1 (a) and H.amazonensis JPM4 (b) under laboratory conditions ( $26 \pm 2^{\circ} \mathrm{C}$ and $12 \mathrm{~h}$ photophase).

\section{Greenhouse bioassay}

According to the mortality rates of $H$. armigera pupae in a greenhouse using different concentrations of $H$. amazonensis MC01, there was a higher mortality of pupae as the concentration of IJs increased. Mortality reached values of $80 \%$ after 10 days, at concentrations of 600 and 800 IJs. Thus, the lowest number of nematodes that caused a high mortality was considered the concentration of $600 \mathrm{IJ}$ s. It was also observed that from the sixth to the eighth day there was an increase in mortality, and on the tenth day there was low incidence of dead pupae. The action of the nematode on the pupae occurred mainly between 6 and 8 days after the inoculation of the infective juveniles (Fig. 2).

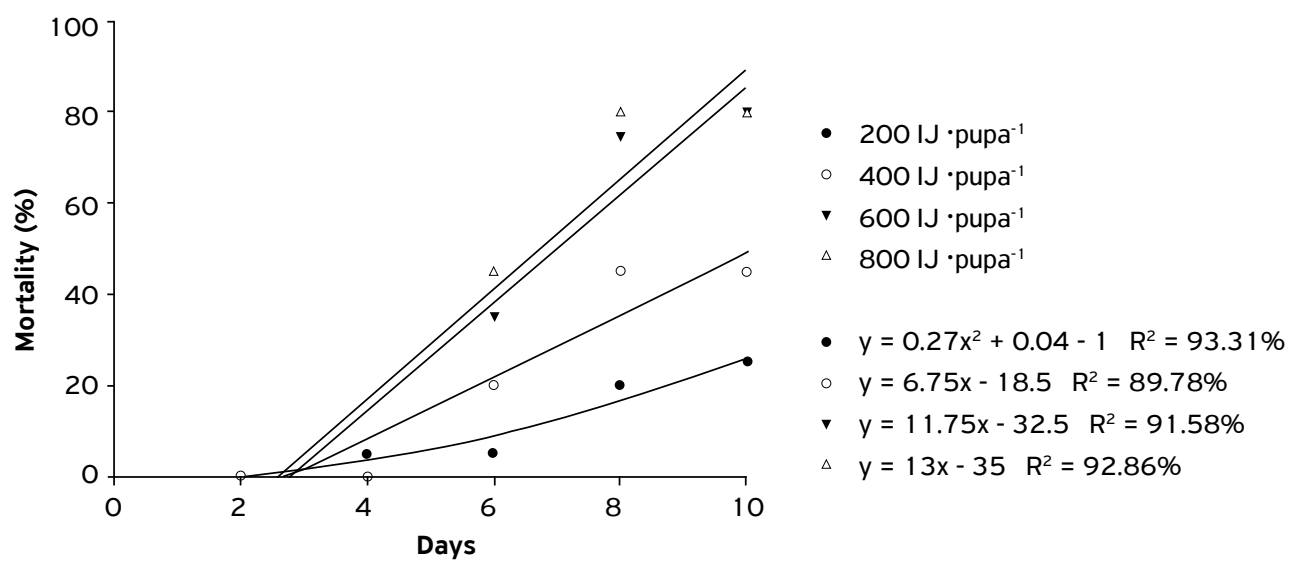

Figure 2. Mortality of $H$. armigera pupae using different concentrations of $H$. amazonensis MCO 1 under greenhouse conditions.

Considering S. carpocapsae All, there was an increment in mortality as the concentration of IJs increased. There was also an increase in pupal mortality from the sixth day of evaluation. Thus, at the highest concentrations tested, 600 and $800 \mathrm{IJs}$, there was the highest pupal mortality rate. The highest mortality was observed at 8 days after the juvenile application, at a concentration of $600 \mathrm{IJs}$ (reaching $80 \%$ mortality). This percentage of mortality was also obtained at the concentration of 800 IJs, but only 10 days after the IJs inoculation (Fig. 3).

\section{Field bioassay}

The interaction between the treatments and days was significant $(\mathrm{p}<0.01)$. A gradual increase occurred in the mortality of $H$. armigera pupae caused by H. amazonensis $\mathrm{MC} 01$ over time. From the second day of evaluation, there was an increase in pupal mortality, which stabilized on the fifth day of evaluation. In the two initial evaluations, treatment with IJs suspension caused higher mortality than treatment with T. molitor cadaver. However, in the subsequent evaluations, these treatments were similar, with 77 and $75 \%$ of pupal mortality, respectively, in the last evaluation (Fig. 4). In the control, pupal mortality reached a maximum value of $15 \%$, related to environmental factors and adults that had emerged. 


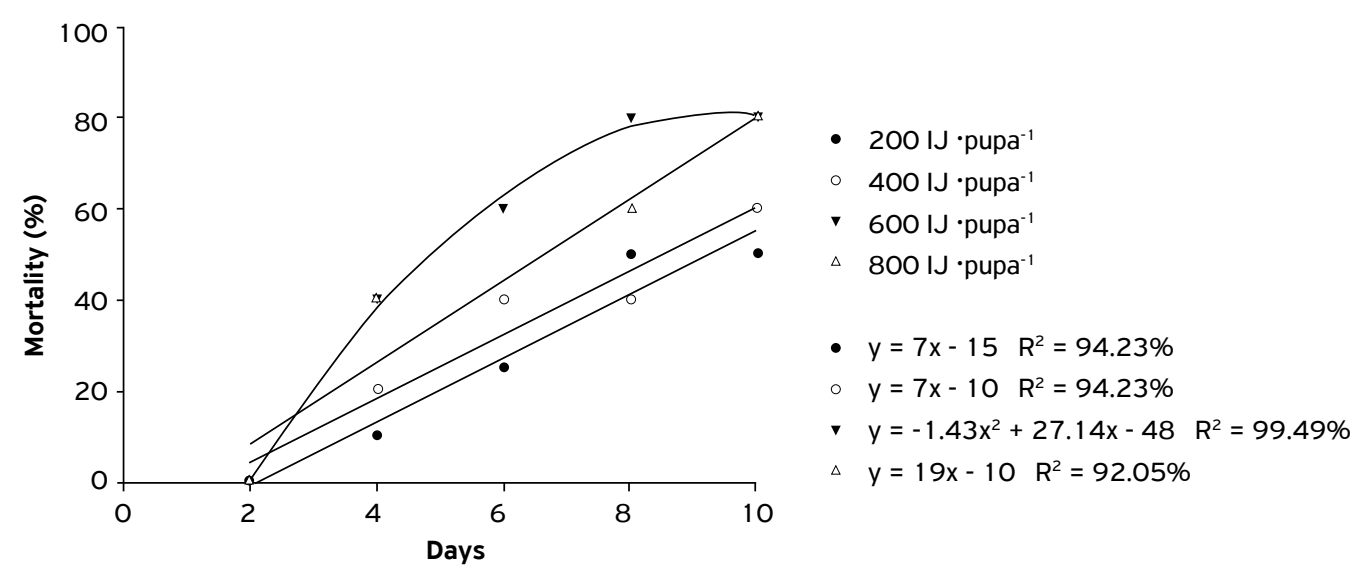

Figure 3. Mortality of $H$. armigera pupae using different concentrations of S. carpocapsae. All under greenhouse conditions.

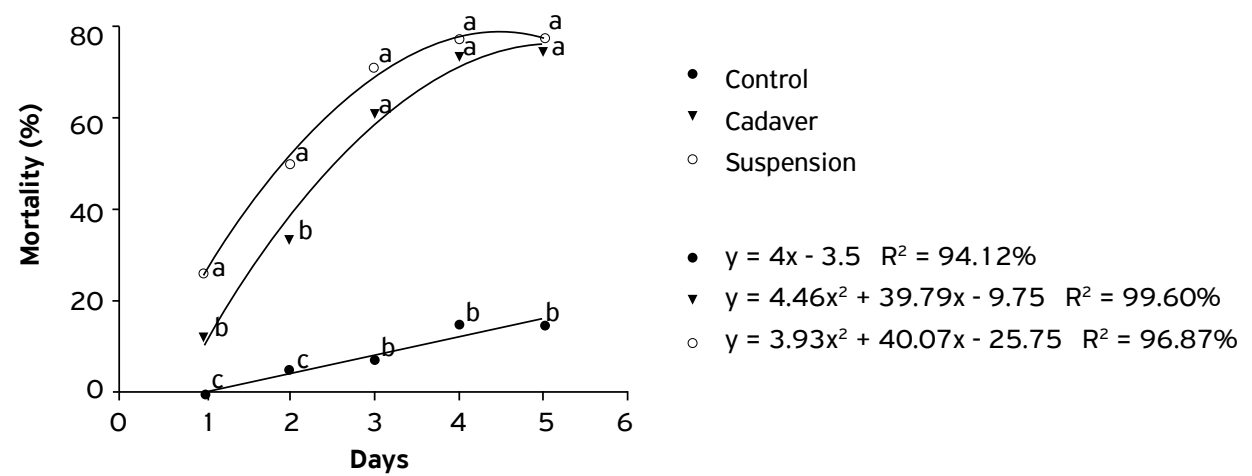

Figure 4. Mortality of $H$. armigera pupae caused by $H$. amazonensis MCO1 under field conditions. Same letters associated to the observed means for each day indicate that the treatments do not differ by Tukey test at $5 \%$ probability.

\section{DISCUSSION}

Considering studies with species of similar behavioral habits in the pupal phase and close taxonomic category, it is possible to make inferences with studies developed with other Noctuidae, such as $S$. frugiperda. The virulence of $S$. frugiperda larvae was studied by FUXA et al. (1988), and it was observed that there were variations in mortality caused by different populations of the same nematode species, Steinernema feltiae (Filipjev).

MOLINA-OCHOA et al. (1996) affirmed that S. carpocapsae, Steinernema riobravis Cabanillas, Poinar and Raulston, and Heterorhabditis megidis Poinar, Jackson and Klein were nematodes considered potential in the control of $S$. frugiperda, while ANDALÓ et al. (2010) obtained higher mortality rates using the nematodes S. arenarium A11 (Artyukhovsky) and H. amazonensis RSC02. CACCIA et al. (2014) verified under laboratory conditions that Steinernema diaprepesi Nguyen and Duncan caused mortality rates to larvae of S. frugiperda from 93 to $100 \%$ and 87 to $93 \%$ for Helicoverpa gelotopoeon (Dyar).

In addition, mortality rates could also vary depending on the nematode populations tested and the susceptibility of the insect population. According to RAULSTON et al. (1992), prepupae and pupae of S. frugiperda suffered $46 \%$ mortality when using Steinernema sp.; whereas MOLINA-OCHOA et al. (1996) obtained pupae mortality rates of at most $43 \%$. These indices are lower than those found for larvae, which can be attributed to the difficulty experienced by nematodes when trying to penetrate the pupae. However, few studies were conducted using entomopathogenic nematodes on pupae of H. armigera.

MOLINA-OCHOA et al. (1996), studying the efficiency of different nematode species to control S. frugiperda, obtained data showing that $H$. bacteriophora caused mortality of $64.7 \%$ in caterpillars of this species at a concentration of $100 \mathrm{IJs} \cdot \mathrm{mL}^{-1}$, but with low mortality in pupae (5.7\%). Thus, it is important to select the correct concentration of isolates of these entomopathogenic organisms in order to avoid possible failures in treatments or unnecessary expenses.

According to ALVES et al. (2009), it is very important to conduct studies with nematode concentrations in the laboratory, due to the fact that the use of EPNs only tends to be economically viable when smaller concentrations are required, generating a lower final cost for nematode production. 
Therefore, considering that both nematodes H. amazonensis JPM4 and H. amazonensis MC01 were virulent to $H$. armigera pupae, $H$. amazonensis MC01 was selected for further tests, since it is a native population of the study region, isolated in the municipality of Monte Carmelo, MG, Brazil, already adapted to the local environmental conditions.

SOUZA et al. (2012) developed experiments in greenhouse conditions and obtained that at concentrations of 150, 300 and $600 \mathrm{IJs} \cdot$ insect $^{-1} \mathrm{H}$. amazonensis RSC05 caused mortality in S. frugiperda similar to that found in the tests with H. armigera, reaching values close to $80 \%$, corroborating the data obtained in the present study.

According to ALI et al. $(2007,2008)$ Steinernema seemae Ali, Shaheen, Pervez and Hussain applied for control of H. armigera larvae and prepupae was promising as a pest control agent, due to the high mortality rates observed. NAVON et al. (2002) have demonstrated the potential of nematodes application in the field, since they can remain in the soil for a long period of time, which could continue causing mortality of the pest for several years of cultivation.

\title{
CONCLUSION
}

Heterorhabditis amazonensis MC01 at the concentration of $400 \mathrm{IJs} \cdot$ pupa $^{-1}$ promoted higher mortality in H. armigera pupae. Heterorhabditis amazonensis MC01 and S. carpocapsae All were effective in controlling H. armigera pupae at concentrations of $600 \mathrm{IJs} \cdot$ pupa $^{-1}$ under greenhouse conditions. Heterorhabditis amazonensis MC01 was effective causing mortality to $H$. armigera pupae in the field when applied as an aqueous suspension and using the T. molitor cadaver under the tested conditions.

\author{
AUTHORS' CONTRIBUTIONS \\ Conceptualization: Andaló, V.; Assis, G.A.; Faria, L.S. Data curation: Andaló, V.; Assis, G.A. Formal analysis: Carvalho, F.J.; \\ Funding acquisition: Andaló, V.; Assis, G.A.; Santos, V.; Mendes, S.M.; Gonring, A.H.R. Methodology: Andaló, V.; Assis, G.A.; Faria, \\ L.S. Project administration: Andaló, V.; Writing - review \& editing: Andaló, V.; Assis, G.A.; Faria, L.S.; Carvalho, F.J.; Santos, V.; \\ Mendes, S.M.; Gonring, A.H.R.
}

\section{AVAILABILITY OF DATA AND MATERIAL}

All data generated or analyzed during this study are included in this published article.

FUNDING

Fundação de Amparo à Pesquisa do Estado de Minas Gerais

CAG - APQ-00075-14

http://dx.doi.org 10.13039/501100004901

CONFLICTS OF INTEREST

All authors declare that they have no conflict of interest.

ETHICAL APPROVAL

Not applicable.

\section{ACKNOWLEDGEMENTS}

The authors would like to thank Universidade Federal de Uberlândia.

\section{REFERENCES}

AKHURST, R.J.; JAMES, W.; BIRD, L.J.; BEARD, C. Resistance to the Cry1Ac $\delta$-Endotoxin of Bacillus thuringiensis in the cotton bollworm, Helicoverpa armigera (Lepidoptera: Noctuidae). Journal of Economic Entomology, Annapolis, v.96, n.4, p.1290-1299, 2003. https://doi.org/10.1093/jee/96.4.1290

ALI, S.S.; PERVEZ, R.; HUSSAIN, M.A.; AHMAD, R. Effect of temperature on survival of Steinernema seemae, S. masoodi and S. carpocapsae (Rhabditida: Steinernematidae) and their subsequent infectivity to prepupa of Helicoverpa armigera (Hübner). Archives of Phytopathology and Plant Protection, Quebec, v.40, n.3, p.183-187, 2007. https://doi.org/10.1080/03235400500383750 
ALI, S.S.; PERVEZ, R.; HUSSAIN, M.A.; AHMAD, R. Susceptibility of three lepidopteran pests to five entomopathogenic nematodes and in vivo mass production of these nematodes. Archives of Phytopathology and Plant Protection, Quebec, v.41, n.4, p.300-304, 2008. https://doi.org/10.1080/03235400600759396

ALVES, V.S.; MOINO JUNIOR, A.; SANTA-CECILIA, L.V.C.; ANDALÓ, V.; SOUZA, G.C. Patogenicidade de nematoides entomopatogênicos à cochonilha da raiz do cafeeiro Dysmicoccus texensis (Tinsley) (Hemiptera: Pseudococcidae) em laboratório. Arquivos do Instituto Biológico, São Paulo, v.76, p.67-73, 2009.

ANDALÓ, V.; MOREIRA, G.F.; MOINO JUNIOR, A. Host-seeking behavior of the Heterorhabditis amazonensis nematode in response to stimulant sources. Pesquisa Agropecuária Tropical, Goiânia, v.47, n.3, p.265-272, 2017. https://doi.org/10.1590/1983-40632016v4745395

ANDALÓ, V.; NGUYEN, K.B.; MOINO JUNIOR, A. Heterorhabditis amazonensis n. sp. (Rhabditida: Heterorhabditidae) from Amazonas, Brazil. Nematology, Bedfordshire, v.8, n.6, p.853-867, 2006. https://doi.org/10.1163/156854106779799286

ANDALÓ, V.; SANTOS, V.; MOREIRA, G.F.; MOREIRA, C.C.; MOINO JUNIOR, A. Evaluation of entomopathogenic nematodes under laboratory and greenhouses conditions for the control of Spodoptera frugiperda. Ciência Rural, Santa Maria, v.40, n.9, p.1860-1866, 2010. https://doi.org/10.1590/S0103-84782010005000151

ARTHURS, S.; HEINZ, K.M.; PRASIFKA, J.R. An analysis of using entomopathogenic nematodes against above-ground pests. Bulletin of Entomological Research, Brisbane, v.94, n.4, p.297-306, 2004. https://doi.org/10.1079/BER2003309

ÁVILA, C.J.; VIVAN, L.M.; TOMQUELSKI, G.V. Ocorrência, aspectos biológicos, danos e estratégias de manejo de Helicoverpa armigera (Hübner) (Lepidoptera: Noctuidae) nos sistemas de produção agrícolas (Circular técnica 23). Dourados: Embrapa Agropecuária Oeste, 2013. Available from: http://www.cnpso.embrapa.br/caravana/pdfs/FINAL_Circular_Tecnica_23_CPAO(1).pdf. Access on: 8 Dec. 2020.

CACCIA, M.G.; DEL VALLE, E.; DOUCET, M.E.; LAX, P. Susceptibility of Spodoptera frugiperda and Helicoverpa gelotopoeon (Lepidoptera: Noctuidae) to the entomopathogenic nematode Steinernema diaprepesi (Rhabditida: Steinernematidae) under laboratory conditions. Chilean Journal of Agricultural Research, Chillán, v.74, n.1, p.123-126, 2014. https://doi.org/10.4067/S0718-58392014000100019

CZEPAK, C.; VIVAN, L.M.; ALBERNAZ, K.C. Praga da vez. Cultivar: Grandes Culturas, v. 167, p. 20-27, 2013.

FEASTER, M.A.; STEINKRAUS, D.C. Inundative biological control of Helicoverpa zea (Lepidoptera: Noctuidae) with the entomopathogenic nematode Steinernema riobravis (Rhabditida: Steinernematidae). Biological Control, Sophia Antipolis, v.7, n.1, p.38-43, 1996. https://doi. org/10.1006/bcon.1996.0061

FUXA, J.R.; RICHTER, A.R.; AGUDELO-SILVA, F. Effect of host age and nematode strain on susceptibility of Spodoptera frugiperda to Steinernema feltiae. Journal of Nematology, College Park, v.20, n.1, p.91-95, 1988. Available from: https://www.ncbi.nlm.nih.gov/pmc/ articles/PMC2618776/. Access on: 8 Dec. 2020.

JHA, R.K.; CHI, H.; TANG, L.-C. A comparison of Artificial Diet and Hybrid Sweet Corn for the Rearing of Helicoverpa armigera (Hübner) (Lepidoptera: Noctuidae) Based on Life Table Characteristics. Environmental Entomology, Annapolis, v.41, n.1, p.30-39, 2012. https://doi.org/10.1603/EN11206

KAMARAJ, C.; RAHUMAN, A.A.; BAGAVAN, A. Screening for antifeedant and larvicidal activity of plant extracts against Helicoverpa armigera (Hübner), Sylepta derogata (F.) and Anopheles stephensi (Liston). Parasitology Research, Melville, v.103, p.1361, 2008. https:// doi.org/10.1007/s00436-008-1142-x

LAMMERS, J.W.; MACLEOD, A. Report of a pest risk analysis: Helicoverpa armigera (Hübner, 1808). Plant Protection Service (NL) and Central Science Laboratory (UK) joint Pest Risk Analysis for Helicoverpa armigera. 2007. Available from: https://secure.fera.defra.gov. uk/phiw/riskRegister/downloadExternalPra.cfm?id=3879. Accessed on: 18 Out. 2019.

MAPA. MINISTÉRIO DA AGRICULTURA, PECUÁRIA E ABASTECIMENTO. Agrofit. 2020. Available from: http://agrofit.agricultura. gov.br/agrofit_cons/principal_agrofit_cons. Accessed on: 9 Sep. 2020. 
MOLINA-OCHOA, J.; HAMM, J.J.; GUTIERREZ, R.L.; BOJALIL-JABER, L.F.; VARGAS, M.A.; GONZÁLES, M.R. Virulence of six entomopathogenic nematodes (Steinernematidae and Heterorhabditidae) on immature stages of Spodoptera frugiperda (Lepidoptera: Noctuidae). Vedalia Revista Internacional de Control Biológico, Mexico, v.3, n.1, p.25-29, 1996.

NAVON, A.; NAGALAKSHMI, K.; LEVSKI, S.; SALAME, L.; GLAZER, I. Effectiveness of entomopathogenic nematodes in an alginate gel formulation against lepidopterous pests. Biocontrol Science and Technology, Sassari, v.12, n.6, p.737-746, 2002. https://doi. org/10.1080/0958315021000039914

NGUYEN, K.B.; GINARTE, C.M.A.; LEITE, L.G.; SANTOS, J.M.; HARAKAVA, R. Steinernema brazilense n. sp. (Rhabditida: Steinernematidae), a new entomopathogenic nematode from Mato Grosso, Brazil. Journal of Invertebrate Pathology, Champaign, v.103, n.1, p.8-20, 2010. https://doi.org/10.1016/j.jip.2009.09.004

POTRICH, T.D.; LORINI, I.; VOSS, M.; STEFFENS, M.C.S.; PAVANI, D.P. Metodologia de criação de Tenebrio molitor em laboratório para obtenção de larvas (Documentos online 82). Passo Fundo: Embrapa Trigo, 2007. Available from: http://www.cnpt.embrapa.br/biblio/ do/p_do82_12.htm. Access on: 8 Dec. 2020.

RAULSTON, J.R.; PAIR, S.D.; LOERA, J.; CABANILLAS, H.E. Prepupal and Pupal Parasitism of Helicoverpa zea and Spodoptera frugiperda (Lepidoptera: Noctuidae) by Steinernema sp. in Cornfields in the Lower Rio Grande Valley. Journal of Economic Entomology, Annapolis, v.85, n.5, p.1666-1670, 1992. https://doi.org/10.1093/jee/85.5.1666

SOUZA, L.M.; MOINO JÚNIOR, A.; MERTZ, N.R.; SILVA, M.A.T.; SOARES, F.M.; BONETE FILHO, R.Z. Nematoides entomopatogênicos e compatibilidade com imidaclopride visando ao controle de Spodoptera frugiperda em viveiro florestal. Nematologia Brasileira, Piracicaba, v.36, n.1-2, p.32-41, 2012.

UDAMALE, S.K.; MOHARIL, M.P.; UGALE, T.B.; MANKAR, J.M. Differential Inhibition of Helicoverpa armigera (Hübner) gut proteinases by proteinase inhibitors of okra and it's wild relatives. ISRN Biotechnology, v.2013, p.632173, 2013. Available from: https://www.hindawi. com/journals/isrn/2013/632173/. Access on: 8 Dec. 2020.

VILELA, M., et al. Metodologia para criação e manutenção de Helicoverpa armigera em laboratório (Circular Técnica 203). Sete Lagoas: Embrapa Milho e Sorgo, 2014. Available from: https://ainfo.cnptia.embrapa.br/digital/bitstream/item/117129/1/circ-203.pdf. Access on: 8 Dec. 2020.

WILSON, M.J.; EHLERS, R.-U.; GLAZER, I. Entomopathogenic nematode foraging strategies: is Steinernema carpocapsae really an ambush forager? Nematology, Bedfordshire, v.14, p.389-394, 2012. https://doi.org/10.1163/156854111X617428 